\title{
Political elections and corporate investment: International evidence
}

\author{
Mario Daniele Amore ${ }^{1}$ and \\ Margherita Corina ${ }^{1}$
}

${ }^{1}$ Department of Management and Technology, Bocconi University, Via Roentgen 1, 20136 Milan, Italy

Correspondence:

MD Amore, Department of Management and Technology, Bocconi University, Via Roentgen 1, 20136 Milan, Italy e-mail: mario.amore@unibocconi.it

\begin{abstract}
Recent literature shows that the spike in uncertainty during political elections harms firms' investment. Bridging insights from international business and political science, we argue that the effect of political elections on firms' investment activities is contingent on the country's electoral system. In particular, we expect the negative effect of elections on corporate investment to be smaller for firms operating in plurality systems. We test our theory using a panel dataset of listed firms around the world, and a panel of US multinationals. Our results confirm that during an election period, firms in countries with a plurality system reduce investment less than firms in other countries. Additionally, we show that multinationals' foreign investment is affected by elections abroad: their investment in a host country declines during an election in that country, though to a lesser extent if the election is held with a plurality system. Collectively, our findings provide new evidence on the role of political institutions for firms' investment decisions.
\end{abstract}

Journal of International Business Studies (2021) 52, 1775-1796.

https://doi.org/ | 0.1057/s41267-021-00421-6

Keywords: political uncertainty; investment; electoral systems; multinationals

The online version of this article is available Open Access

\section{INTRODUCTION}

A central question in management research has revolved around how firms respond to "environmental uncertainty", defined as a set of hard-to-predict events that - by increasing the amount of information that a firm has to gather and elaborate to achieve a given performance level, or by weakening relationships with exchange partners - impair the ability to plan and operate deterministically (Bode et al. 2011; Thompson, 1967; Van de Ven, 1979; Van de Ven \& Drazin, 1985).

Strategy scholars have traditionally focused on various sources of environmental uncertainty such as economic shocks (Chakrabarti, 2014), demand fluctuations (Bennett \& Hall, 2020), regulatory changes (Dutt \& Joseph, 2019; Fabrizio, 2013), and natural disasters (Oh \& Oetzel, 2011). Motivated by policy discussions in the aftermath of the 2008-2009 financial crisis, scholars have begun to explore a specific type of uncertainty stemming from the political
Received: 4 April 2020

Revised: 16 February 2021

Accepted: 21 February 2021

Online publication date: 19 April 2021 
sector, i.e., political uncertainty, defined as the irresolution about the policies and regulations that a new government will put in place (Baker et al. 2016; Blake \& Jandhyala, 2019; Bloom, 2014).

Political environments are perceived to be increasingly uncertain (Davis, 2019) due to contentious events such as the surge of populist parties or the Brexit referendum (Cumming \& Zahra, 2016; Moschieri \& Blake, 2019). Accordingly, corporate executives have expressed growing concerns about the role of political risk for the companies they manage (Giambona et al. 2017). Existing evidence shows that political uncertainty harms a broad array of corporate policies including investment, IPOs, disclosure, dividends, and foreign activities (Amore, 2020; Baker et al. 2016; Bonaime et al. 2018; Colak et al. 2017; Gulen \& Ion, 2016; Huang et al. 2015; Lee, 2018). ${ }^{1}$

Identifying the causal effect of political uncertainty on firms' outcomes has proven to be challenging due, for instance, to the fact that political uncertainty correlates with business cycle conditions. A recent research has thus suggested to take advantage of variations in electoral cycles, which are largely fixed and unaffected by economic or business conditions. Political elections escalate political uncertainty since different candidates who run for office have different priorities, and voting results are often hard to predict. Because the timing of elections is not perfectly correlated across countries, firms in non-election countries can provide a counterfactual for firms in election countries at a given point in time, after controlling for constant heterogeneity and time-varying economic conditions. Several works based on this approach have shown that during election periods companies experience a significant drop in investment activities (e.g., Amore \& Minichilli, 2018; Jens, 2017; Julio \& Yook, 2012, 2016). In this article, we investigate how a country's electoral system shapes the effect of election cycles on corporate investment. As we shall argue, this assessment is useful to uncover how political uncertainty may propagate to the business landscape.

Electoral systems are the set of rules determining how votes are converted into seats (Norris, 1997); they are typically classified using various attributes, the most important of which is the electoral rule. The two polar rules are proportional and plurality. In a plurality system, candidates win a seat if they get more votes than their closest rival in a constituency, whereas in a proportional system candidates are elected based on the overall percentage of votes received by their party, and seats are distributed accordingly (Blais \& Massicotte, 1997; Persson \& Tabellini, 2004). The political science literature has shown that proportional systems can provide a higher representation of minorities and a better balance between different political parties (Lijphart, 1994). To achieve this balance, electoral proportionality gives rise to coalition or minority governments (e.g., Persson, Tabellini, \& Trebbi, 2003; Powell \& Powell, 2000), whose agendas require the convergence of broader, and potentially also less cohesive, political interests through complex pre- and post-election bargaining processes. Typically, these processes take time to unfold and their outcome is difficult to foresee. As a consequence, at the time of an election - and often even after the election result has been announced there is a relatively high uncertainty about the policies the new government will implement. Several examples, from the 2010 Belgian general elections to the 2017 Netherlands general election, show how complex it can be to appoint a ruling coalition under a proportional system. The bargaining process between political parties lasted several months, and the ultimate political agenda that the government decided to pursue was uncertain until the moment when the government was appointed. By contrast, in countries with a plurality rule - even when the election is highly contested, such as in the US in 2016 or France in 2017 - voting results translate more directly into policy outcomes (Indridason, 2011), the prediction over future policies is more straightforward (Vuchelen, 2003), and the new government is typically appointed soon after the voting date. Collectively, these arguments suggest that electoral systems can shape the impact of electoral cycles on corporate policies: the negative effect of elections on investment is expected to be larger for firms in countries with a proportional system.

Going back to Rugman (1976), international business scholars have argued that multinationality provides risk-diversification opportunities. Operating in multiple countries allows firms to manage unsystematic risks (Hitt et al. 2006), for instance by holding back projects in countries that become more uncertain and exploit investment opportunities elsewhere (Sarkar, 2020). Therefore, multinationality may improve the ability to hedge against political risk (Hill et al. 2019; Nguyen et al. 2018). Other scholars, however, have contended that multinationality may not reduce systemic risks 
(Reeb et al. 1998; Reuer \& Leiblein, 2000), and that political uncertainty is generally difficult to be diversified away (Pastor \& Veronesi, 2013). We argue that running operations in foreign countries exposes multinationals to multiple idiosyncratic sources of political uncertainty. Accordingly, the surge in political uncertainty due to elections in a host country can undermine the foreign investment of multinational firms in that country. Yet, consistent with our previous hypothesis, we expect this effect to be lower if the host country adopts a plurality system.

To test these hypotheses, we analyze a panel dataset covering firms in 39 countries around the world. Our results show that during an election, companies reduce investment significantly less when the election is held with a plurality system, as compared to other electoral systems. Additionally, we find that the foreign investment of multinationals in a foreign country declines when that country holds political elections, and that such decline is attenuated by plurality systems.

Our work contributes to a vibrant literature about the influence of electoral cycles on business outcomes (e.g., Amore \& Minichilli, 2018; Colak et al. 2017; Jens, 2017; Julio \& Yook, 2012, 2016; Liu \& Ngo, 2014). While many works in this area have focused on the impact of political elections on investment decisions, they have not yet explored the important role played by the system according to which elections are held. This void is surprising in light of voluminous research arguing that electoral systems have pervasive effects not only on the nature of government policies (e.g., Persson \& Tabellini, 2004) but also on business conditions (Zingales, 2017), and companies' structures and policies (Choy et al. 2011; Pagano \& Volpin, 2005). With a few notable exceptions (Julio \& Yook, 2016; Sarkar, 2020), a common tenet of the literature has been the direct analysis of political elections and investment in the country of firms' headquarters. Going beyond this approach, we focus on multinational firms and explore the sensitivity of investment to the political conditions in the foreign countries where they operate. In so doing, we also expand the literature on the role of political institutions for corporate strategies. Works in this area have studied a wealth of institutional characteristics at the international and local level (Chan et al. 2010; Delios \& Henisz, 2003; Filippaios et al. 2019; Holburn \& Zelner, 2010; Mudambi \& Navarra, 2003; Murtha \& Lenway, 1994) also including political risk factors (Azzimonti, 2019;
Beazer \& Blake, 2018; Liu \& Li, 2020). Yet, the role of electoral systems has been largely neglected. Our work fills this gap.

In the next section, we provide an account of current debates about the effect of political uncertainty on firms' investment, and describe the research gaps that we wish to address. Then, we develop our hypotheses. We move to explain our data and variables, and present our findings together with a battery of robustness checks. Finally, we discuss the implications of our findings and conclude.

\section{POLITICAL UNCERTAINTY AND CORPORATE DECISION-MAKING}

Beckman et al. (2004) defined uncertainty as "the difficulty firms have in predicting the future, which comes from incomplete knowledge". Thompson (1967) argued that uncertainty is a key feature of the environment in which firms operate, and that it can profoundly shape managers' decision-making. These concepts have been extensively discussed in the organization and strategy literature, particularly among theorists who aimed at unfolding the complex nature of interactions between organizations and their environment.

Research in this area has studied uncertainty in its various forms by distinguishing between firmspecific and market-specific uncertainty (Beckman et al. 2004). The first type of uncertainty originates from changes that are internal to the firm, such that entering a new market (Greve, 1996), acquiring another firm (Haunschild, 1994), or positioning plants internationally (Henisz \& Delios, 2001). The second type relates to external factors, e.g., macroeconomic events, which affect all firms operating within a given context (Beckman et al. 2004).

Uncertainty can have significant implications on a firm's strategy, and a large stream of research has been devoted to understanding how firms make decisions under uncertainty (Courtney et al. 1997; Wernerfelt \& Karnani, 1987). For instance, there is evidence that firm-level uncertainty increases imitation by complicating predictions about future performance (Gaba \& Terlaak, 2013). By contrast, market-specific uncertainty has been shown to reduce the precision in the information that can be inferred from others, thereby reducing imitation. Other works in this area study how different types of uncertainty impact a variety of actions including network partner selection (Podolny, 
1994) and the governance of inter-firm relationships (Carson et al. 2006; Krishnan et al. 2016).

A specific type of environmental uncertainty that has received significant scrutiny is the one related to politics (Baker et al. 2016). Firms deal constantly with the political sector to get resources, procurement contracts, and various other types of business opportunities (Amore \& Bennedsen, 2013). Thus, government activities are key to many corporate decisions involving investment and financing. The amount of uncertainty over government activities, which continuously change as a function of microand macro-level factors (Yan \& Chang, 2018), tends to spike during political elections due to the difficulty in foreseeing the voting outcomes, the composition of the new government, and the policies that will be implemented (Vuchelen, 2003). The inability to perfectly forecast the results of an election, and the uncertainty surrounding government policies can thus harm financial performance or restrain firms from meeting future targets (Kingsley et al. 2012). Indeed, political processes that alter the costs of making new or reversing existing policies (Blake \& Jandhyala, 2019) have a substantial impact on strategic actions (Henisz \& Delios, 2001). Due to these considerations, companies are attentive to political decisions that can impact their activities, especially those that are costly to adjust in the short term.

Political uncertainty can discourage firms' irreversible actions due to real-option considerations: uncertainty increases the incentives to wait to get new information rather than committing early (Bernanke, 1983; Wernerfelt \& Karnani, 1987). Moreover, different from many sources of risk, policy uncertainty is hard to be diversified away, and thus increases borrowing costs via an increase in risk premia (Pastor \& Veronesi, 2012). Because corporate investment is often not easily reversible, heightened uncertainty in the period surrounding an election is expected to make firms more cautious in their investment and financing policies. Building on these notions, existing works have shown that firms delay investment activities until the uncertainty regarding future regulations and economic policies is resolved (Amore \& Minichilli, 2018; Jens, 2017; Julio \& Yook, 2012). A parallel inquiry in non-market strategy research has shown that firms use a variety of strategies (e.g., lobbying, contributions) to gain influence or improve their access to the public-policy process (Hillman \& Hitt, 1999), both in their home country as well as in the foreign countries where they operate (Brown et al. 2018).
While political uncertainty has been the cornerstone of vibrant literature in economics and finance, the topic is still scarcely investigated among management scholars, who have been traditionally more interested in firm- or industryspecific uncertainty. The international business literature provides some notable exceptions, though. Following Dunning (1981), several scholars have developed theoretical models showing how firms' decisions to invest abroad are affected by the economic and political conditions of the host country (see Faeth, 2009 for a review). A key work in this area is Henisz (2000), which analyzes the relationship between political hazard and multinationals' entry mode. In a similar vein, Delios and Henisz (2003) uses a sample of Japanese manufacturers to show that policy uncertainty can discourage foreign investment. James and Vaaler (2018) contends that the adverse effects of policy risk on firms' investment can be ameliorated by a state's minority equity stake. Lee (2018) further shows that political uncertainty influences in crossborder acquisitions, whereas Zhong et al. (2019) argues that the political risk stemming from politicians' turnover harms foreign subsidiaries' performance. While these works have largely focused on developing countries with unstable political environments, recent evidence shows that the policy risk arising from the contentiousness of political actions harms foreign investment even in a country with sound institutions like the US (Azzimonti, 2019). In this debate, it is worth noting that the political institutions of both host and home countries may play a role in determining foreign investment decisions (Beazer \& Blake, 2018). Collectively, this research establishes that political uncertainty has significant implications for corporate policies.

Political economy scholars too have investigated the role of political institutions for economic outcomes, taking mostly a macroeconomic stance. Works in this area have asked, for instance, whether democracy can improve economic growth (Przeworski \& Limongi, 1993), and to what extent political risk harms a country's economic performance (Alesina et al. 1996). Existing works have also contended that electoral rules, i.e., the electoral system used to establish the winner and then appoints a government, affect economic outcomes (see Persson \& Tabellini, 2004 for a review). This research, however, has not probed into the implications of electoral rules for firm-level strategies and results. 
We bridge the research streams in international business and political economy by exploiting the context of elections and delving into the neglected role of electoral systems for corporate investment. In particular, we will argue that electoral systems can moderate the effect of elections on firms' investment. Next, we will explore how elections in the host country shape the foreign investment of multinational firms.

\section{THEORETICAL BACKGROUND}

\section{Electoral Systems: An Overview}

An electoral system comprises three features (Persson \& Tabellini, 2004). The first, district magnitude, determines the number of legislators that get a seat in a given district (with the two extremes being a single countrywide district which elects all politicians, and multiple districts each electing one politician). The second, ballot structure, concerns how voters cast their ballot, i.e., whether they can choose among individual candidates or lists of party candidates. The third is the electoral rule used to divide votes into seats, i.e., whether the politician who gets the highest share of votes in a district is elected (plurality rule), or whether seats are assigned to parties proportionally to the votes received in each district (proportional rule). As many have noted, these features are correlated across countries: plurality rules tend to be implemented along with single voting ballots in narrow districts, whereas proportional rules tend to be implemented along with party lists and large districts. Operationalizing the proportionality (or plurality) of electoral systems is a complex exercise. Some empirical works have adopted discrete measures which distinguish between proportional and plurality (Persson et al. 2003; Persson, Roland, \& Tabellini, 2007; Bormann \& Golder, 2013). However, many electoral systems combine features of both proportionality and plurality, and may have a varying degree of proportionality. Thus, scholars (e.g., Carey \& Hix, 2011; Taagepera, 2002) have stressed the importance of considering the potential trade-offs between the different features of an electoral system, and adopting continuous measures that can capture the degree of (dis)proportionality more thoroughly.

The intuition behind our work is that plurality and proportional systems can command a different level of uncertainty about future government policies. Let us start with some examples. During the US presidential elections in 2016, Donald Trump's victory came at a huge surprise to many. However, once the electoral result was announced, the uncertainty about whether Trump's policies or Clinton's policies were to be implemented suddenly vanished. An opposite example is provided by the general elections in the Netherlands in 2017, which failed to deliver an overall majority among any political party for a long time. As a result, the Netherlands did not manage to appoint a new government for 225 days. Almost the same happened in Belgium, where the election in 2010 produced a fragmented political landscape, with 11 parties elected, none of them getting more than $20 \%$ of seats, and so the country had 541 days of government without functions. The incumbent Prime Minister in Israel in early 2019 failed to form a governing coalition, which implied the dissolution of the government before going to new elections.

Why was the fate of some elections determined immediately, while others took so long? As we will discuss, part of the answer lies in the electoral system used to determine the political winner and thus appoint a government. In US elections, the plurality system ensured that a government was appointed right after the election and this, in turn, ensured a faster resolution of the electoral uncertainty. In the case of Belgium, which adopts a proportional system, the electoral results led to intense post-election negotiations where multiple parties tried to mold their priorities in order to appoint a coalition government. We will discuss how these different patterns matter for firms' investment decisions along the electoral cycle.

\section{Political Uncertainty and Corporate Investment: The Role of Electoral Systems}

Many works have documented that electoral systems have a significant effect on politicians' behavior (Nannicini et al. 2013) as well as economic policies, i.e., the level and composition of public spending (Lizzeri \& Persico, 2001; Milesi-Ferretti et al. 2002; Persson \& Tabellini, 2004). Here we argue that electoral systems may also influence how firms invest around a political election.

While all electoral systems tend to give some seat advantage to the strongest party, this advantage is less pronounced in proportional and mixed systems, where seats tend to be assigned to a larger number of (relatively smaller) parties (Norris, 1997). ${ }^{2}$ As a result, it is well known that proportional and mixed systems often lead to multiparty or coalition-based governments (Lijphart, 1994; 
Pagano \& Volpin, 2005; Vuchelen, 2003), whose political agendas result from the aggregation of heterogeneous political priorities pertaining to each coalition partner. ${ }^{3}$ In this way, proportional systems increase voters' representation and inclusiveness; if seats are awarded proportionally to the votes received, everyone has some kind of voice in the decision-making process (Hout \& McGann, 2009). The negotiation processes leading to the formation of coalition governments seek to embrace more viewpoints and, in turn, produce policies that are closer to the preferences of the median voter and where each party does not internalize the fiscal costs of spending (Persson et al. 2007). Consistent with this view, there is evidence showing that countries with proportional systems engage in a higher level of government spending, which is also less geographically targeted so as to cater to a broader array of voters (MilesiFerretti et al. 2002).

Key to our theory, proportional systems might raise political uncertainty due to three interrelated factors: (1) an intrinsically higher complexity in the formation of a ruling government (Mudambi \& Navarra, 2004; Pagano \& Volpin, 2005); (2) the lengthening of the electoral cycle occurring from the post-negotiation processes of coalition-building; (3) a lower identifiability of the resulting government policies. As mentioned, after a proportional election, the share of parliamentary seats displays a relatively high level of fragmentation that calls for the formation of multiparty coalitions (Persson et al. 2003). In other words, in countries with proportional systems, the information on the winning party (i.e., the party that got the highest fraction of votes) is relatively less important since the main determinant of future government policies lies in the composition of a multiparty coalition. To make political interests converge towards a common government agenda, multiple parties engage in negotiation processes that typically take some time to work out, and whose fate is hard to forecast. Therefore, both in the polling as well as in the aftermath of an election voters face a higher uncertainty about the government policies that will be implemented as result of a given voting outcome. Relatedly, scholars have argued that proportional systems may hinder government identifiability (see Dow, 2001 and references therein). ${ }^{4}$

By contrast, plurality systems often lead to singleparty majority governments, which are believed to be more stable and accountable than multiparty governments (Blais \& Massicotte, 1997). These features tend to decrease uncertainty about future government policies and their implementations. Indeed, the implementation of such policies does not require to engage in post-elections negotiations with coalition partners (Norris, 1997). In countries with plurality systems, the announcement of the ultimate winner (and thus the prediction over the future policies that will implemented) is more straightforward as it hinges more directly on the identity of the winning party, whose political agenda is largely known before the election (Vuchelen, 2003). As a result, plurality systems typically provide more effective governments (Lijphart, 1994), which carry out policies that reflect more directly the voting outcomes (Dow, 2001; Indridason, 2011). Once the electoral result in a plurality system has been announced, the prediction over future government policies is more straightforward (Vuchelen, 2003) and the electoral uncertainty is resolved more swiftly as compared to a proportional system.

Many influential works such as Julio and Yook (2012) have documented that elections generally drive a period of political uncertainty during which companies decrease investments until a winner is proclaimed and uncertainty diminishes. Collectively, our arguments suggest that this result will be contingent on the electoral system; in particular, plurality systems will reduce the negative first-order effect of elections on corporate investment.

Hypothesis 1: Political elections have a negative effect on firms' investment.

Hypothesis 2: Plurality systems reduce the negative effect of political elections on firms' investment.

\section{Political Uncertainty and Investment Among Multinational Firms}

International business scholars have wrestled with the advantages and disadvantages of diversifying a company's operations across countries. Many studies indicate that multinationality allows firms to exploit scale and scope economies, grants them access to a broader set of investment opportunities, and enables the development of diverse capabilities. Accordingly, scholars (e.g., Daniels \& Bracker, 1989; Grant, 1987) have shown a positive relationship between international diversification and performance. The literature has also argued that being present in multiple countries can provide firms with risk-diversification opportunities (Rugman, 
1976). Multinationals can utilize combinations of organizational and external resources to arbitrage country-specific sources of risk (Kim et al. 1993). ${ }^{5}$ Moreover, they have access to a varied set of investment opportunities accruing from multiple countries subject to different political cycles: whenever policy risk surges in one country, they have the opportunity to exploit investment opportunities elsewhere (Sarkar, 2020). Collectively, these arguments suggest that multinationality may render firms able to, at least in part, hedge against political uncertainty (Hill et al. 2019; Nguyen et al. 2018). Other scholars, however, have challenged the notion that multinational firms are always able to diversity risk. Reeb et al. (1998) show a positive association between internationalization and systemic risk, Reuer and Leiblein (2000) do not find evidence supporting a negative association between multinationality and downside risk, and Tong and Reuer (2007) find a curvilinear relationship between multinationality and risk. In parallel, existing works have suggested that political uncertainty is not fully diversifiable (Brogaard \& Detzel, 2015; Pastor \& Veronesi, 2013).

We argue that, in addition to uncertainty over political decisions within their country of headquarters, multinationals are also subject to swings in political conditions abroad. For example, multinationals have been exposed to the uncertainty regarding Trump's foreign trade policies (Chang et al. 2019). Similarly, the business decisions of many companies in the UK have been influenced by the political turmoil related to the Brexit referendum (see Dhingra et al. 2016 for a discussion). Multinationals' executives make strategic decisions considering not only their national political environment but also the specific characteristics of the countries where they (intend to) operate. Scholars have thus studied how factors such as foreign countries' economic conditions (e.g., Driffield \& Love, 2007; Jorion, 1990), national cultures (Barkema et al. 1996; Kogut \& Singh, 1988; Mudambi \& Navarra, 2003) and geographic and linguistic distance (Johanson \& Vahlne, 1977) influence international expansion decisions (Delios $\&$ Henisz, 2003). Moreover, extant research has analyzed how foreign countries' political environments affect the choice about which markets to enter and the entry mode (Carroll et al. 1988; Henisz, 2000; Mudambi \& Navarra, 2003). Recent works confirm that political conditions matter a great deal for multinationals' investment activities. For instance, Azzimonti (2019) shows that foreign direct investment in the US is affected by party conflicts over trade policies, whereas Liu and Li (2019) shows that terrorism drives divestment decisions. Other factors such as political governance and civil liberties matter too for foreign direct investment decisions (Filippaios et al. 2019).

Generally, these insights suggest that in their decision to expand across national borders, firms would expose themselves to sources of uncertainty about future cash flows in those foreign countries. Coping with these factors may require to dynamically adjust investment over time. One such uncertainty source is precisely the occurrence of political elections in the foreign country. Therefore, consistent with Julio and Yook (2016), our baseline hypothesis suggests that multinationals would be subject to not only political uncertainty stemming from national elections but also political uncertainty due to elections in the foreign countries where they operate. Consequently, multinationals would reduce the amount of cross-border investment in a given country during elections periods. However, drawing on the arguments used in our second hypothesis, we posit that the drop in investment will be contingent on the foreign country's electoral system: the effect is expected to be lower in countries with plurality electoral systems than countries with other electoral systems.

Hypothesis 3: Political elections in the host country have a negative effect on the foreign investment of multinationals.

Hypothesis 4: Plurality systems reduce the negative effect of political elections in the host country on the foreign investment of multinationals.

\section{DATA AND VARIABLES}

Our empirical analysis is based on: (1) a panel dataset of listed firms in 39 democratic countries from 1991 to 2017 (amounting to 262 national elections); and (2) a subsample of US listed firms (for which we have data on foreign activities from 1998 to 2017). To construct these samples, we gather information from different sources covering political elections, firm-level variables, and macroeconomic data.

\section{Election Data}

The elections in our dataset include those to appoint a national government. Detailed data come 
from the Database of Political Institutions 2017 (DPI) assembled by the Inter-American Development Bank (Cruz et al. 2018). The DPI provides annual information about regimes and authority characteristics, about whether presidents are elected directly or via an electoral college, the chief's years in office, the electoral system, the date of election, victory margin and vote shares of each political party.

Following Julio and Yook (2012), the first step was to collect data on the source of executive legitimacy (either presidential or parliamentary) and decide what kind of election (either legislative or executive) was to be considered. In countries with a presidential regime, the supreme executive power is vested in the office of the president, whereas in countries with a parliamentary regime, the executive power is vested in a cabinet that is responsible to the parliament. We used executive elections in countries with presidential regimes. Instead, in countries with parliamentary regimes, we consider legislative elections, which have the foremost influence over the appointment of the prime minister (or premier) who represents the head of the cabinet and leader of the parliament. Out of the 39 countries for which we have usable firm-level data in the global dataset from 1991 to 2017 (as described next), 27 countries are parliamentary and 12 presidential. Table 1 describes the cross-country data by showing the main electoral variables, and the relative number of firm-year observations in each country.

Following again Julio and Yook (2012), we classify election periods by means of a dummy (Election) equal to one for those years in which an election is held no earlier than 60 days prior to the fiscal year-end in year $t$ and no more than 274 days after the fiscal year-end of year $t$. This variable is designed to capture changes in firms' investment decisions in the period leading up to a national election. ${ }^{6}$ We will check that results are robust to simply using a dummy equal to one for election years, and zero otherwise.

Next, we classify the electoral system which determines how votes are converted into seats. As already discussed, there are two polar systems: plurality, where the candidate wins when she/he gets more votes than each individual opponent in a constituency, and proportional (or mixed), where candidates are elected based on the overall percentage of votes received by their party. Yet, electoral systems often display a varying degree or proportionality. Out of the 39 countries in our sample, nine countries (representing 56\% of firmyear observations) have a plurality system, 15 countries (representing 37\% of observations) have a mixed system, and 15 countries (representing 7\% of observations) have a proportional system. ${ }^{7}$ For the analysis, we use both a binary variable distinguishing plurality systems from others, and a continuous variable (i.e., the Gallagher index), largely used by scholars to measure (dis)proportionality in a continuous fashion (e.g., Carey \& Hix, 2011; Gallagher, 1991; Pennisi, 1998). Perfect proportionality means that every party receives exactly the same share of the seats as its share of votes (Gallagher, 1991); however, this situation is uncommon because countries often put in place specific systems that deviate from perfect proportionality. The Gallagher index measures the relative disproportion between the votes received and the seats obtained in a legislature within an electoral system. We used the DPI database to quantify the percentage of seats and votes for each party during an election. When data were not available, we hand-collected them from the International Election Resources dataset.

\section{Firm-Level Data}

To test Hypotheses 1 and 2, we employ a global dataset drawn from Compustat (Global and North America) for the period 1991-2017. To test Hypotheses 3 and 4, which involve multinational firms, we follow existing works (e.g., Denis et al. 2002; Duru \& Reeb, 2002) and focus on US-listed firms with available investment data in the Compustat Segment database from 1998 to $2017 .^{8}$

The dependent variable (Investment) is the amount of capital expenditures scaled by the beginning-of-year book value of total assets (Julio \& Yook, 2012). We control for the firm's financial performance, i.e., the return on assets (ROA), computed as the ratio of earnings before interest, taxes, depreciation and amortization, scaled by beginning-of-year book value of total assets, and Firm size, calculated as the logarithm of the book value of total assets. ${ }^{9}$

\section{Macroeconomic Data}

Our analysis further includes a set of macroeconomic controls useful to alleviate the concern that corporate investment during an election may change as a result of varying economic conditions before or during an election. From the World Development Indicators of the World Bank, we obtain information on a country's economic 
Table 1 Country characteristics

\begin{tabular}{|c|c|c|c|c|c|}
\hline Country & $\begin{array}{l}\text { Observations in the full } \\
\text { sample }\end{array}$ & $\begin{array}{l}\text { Basis of executive } \\
\text { legitimacy }\end{array}$ & $\begin{array}{l}\text { Type of } \\
\text { elections }^{a}\end{array}$ & $\begin{array}{l}\text { Electoral } \\
\text { system }^{b}\end{array}$ & $\begin{array}{l}\text { Election } \\
\text { timing }\end{array}$ \\
\hline Argentina & 1150 & Presidential & Executive & Proportional & Fixed \\
\hline Australia & 22,355 & Parliamentary & Legislative & Mixed & Flexible \\
\hline Austria & 1232 & Parliamentary & Legislative & Proportional & Flexible \\
\hline Belgium & 1592 & Parliamentary & Legislative & Proportional & Flexible \\
\hline Brazil & 4766 & Presidential & Executive & Mixed & Fixed \\
\hline Canada & 13,214 & Parliamentary & Legislative & Plurality & Flexible \\
\hline Chile & 2646 & Presidential & Executive & Plurality & Fixed \\
\hline Colombia & 488 & Presidential & Executive & Proportional & Fixed \\
\hline Czech & 292 & Parliamentary & Legislative & Mixed & Flexible \\
\hline \multicolumn{6}{|l|}{ Republic } \\
\hline Denmark & 2241 & Parliamentary & Legislative & Proportional & Flexible \\
\hline Finland & 2262 & Parliamentary & Legislative & Proportional & Flexible \\
\hline France & 10,572 & Parliamentary & Legislative & Plurality & Fixed \\
\hline Germany & 10,982 & Parliamentary & Legislative & Mixed & Flexible \\
\hline Greece & 2679 & Parliamentary & Legislative & Mixed & Flexible \\
\hline Hungary & 337 & Parliamentary & Legislative & Mixed & Fixed \\
\hline India & 41,313 & Parliamentary & Legislative & Mixed & Flexible \\
\hline Indonesia & 4327 & Presidential & Executive & Proportional & Fixed \\
\hline Ireland & 1123 & Parliamentary & Legislative & Proportional & Flexible \\
\hline Israel & 4188 & Parliamentary & Legislative & Proportional & Flexible \\
\hline Italy & 4370 & Parliamentary & Legislative & Mixed & Flexible \\
\hline Japan & 49,783 & Parliamentary & Legislative & Mixed & Flexible \\
\hline Malaysia & 14,847 & Parliamentary & Legislative & Plurality & Flexible \\
\hline Mexico & 1872 & Presidential & Executive & Mixed & Fixed \\
\hline Netherlands & 2837 & Parliamentary & Legislative & Proportional & Flexible \\
\hline New Zealand & 2100 & Parliamentary & Legislative & Mixed & Flexible \\
\hline Norway & 3237 & Parliamentary & Legislative & Proportional & Fixed \\
\hline Pakistan & 3321 & Parliamentary & Legislative & Plurality & Flexible \\
\hline Peru & 1340 & Presidential & Executive & Proportional & Fixed \\
\hline Philippines & 2729 & Presidential & Executive & Mixed & Fixed \\
\hline Russia & 1223 & Presidential & Executive & Proportional & Fixed \\
\hline Singapore & 9249 & Parliamentary & Legislative & Plurality & Flexible \\
\hline Spain & 2084 & Parliamentary & Legislative & Mixed & Flexible \\
\hline Sri Lanka & 1892 & Presidential & Executive & Proportional & Flexible \\
\hline Sweden & 2484 & Parliamentary & Legislative & Proportional & Fixed \\
\hline Switzerland & 1629 & Parliamentary & Legislative & Mixed & Fixed \\
\hline Thailand & 7563 & Parliamentary & Legislative & Plurality & Flexible \\
\hline UK & 24,056 & Parliamentary & Legislative & Plurality & Flexible \\
\hline United States & 131,693 & Presidential & Executive & Plurality & Fixed \\
\hline Venezuela & 196 & Presidential & Executive & Mixed & Fixed \\
\hline
\end{tabular}

a This variable denotes the type of elections. If the basis of executive legitimacy is presidential, people vote for the president, and we consider the executive elections. If the basis of executive legitimacy is parliamentary, people vote for the parliament, which is in charge to elect the president or prime minister, and we consider the legislative elections.

$\mathrm{b}$ The electoral system is reported as of 2017.

growth (GDP growth), which controls for the effect of economic conditions on investment (Dangl \& $\mathrm{Wu}, 2016)$. To separate out the electoral cycle from other sources of aggregate uncertainty, such as terrorism, trade wars, etc., we control for the annual global Economic Policy Uncertainty (EPU) index. ${ }^{10}$ Finally, we use the International Monetary Fund database to control for two variables related to monetary policy, which has been shown to be an important predictor of corporate investment (Gertler \& Gilchrist, 1994): Money supply (M1), and the interest rate set by the central bank (Interest rate). ${ }^{11}$

\section{Summary Statistics}

Excluding firms with missing values in the firmlevel and macroeconomic controls leaves us with a 
Table 2 Summary statistics

\begin{tabular}{lccrr}
\hline & Observations & Mean & Std. Dev. & Median \\
\hline Investment & 396,261 & 0.062 & 0.097 & 0.031 \\
ROA & 396,261 & 0.033 & 0.325 & 0.087 \\
Firm size & 396,261 & 6.446 & 3.124 & 6.247 \\
GDP growth & 396,261 & 2.030 & 2.482 & 7.880 \\
M1 & 396,261 & 73.815 & 35.645 & 0.104 \\
EPU & 396,261 & 0.1611 & 5.061 & 0.148 \\
Interest rate & 396,261 & 3.959 & 3.118
\end{tabular}

This table shows summary statistics for the firm-level and macroeconomic variables used in the empirical analysis.

total of 396,261 firm-year observations $(39,248$ unique firms) for the global sample. Table 2 reports summary statistics on firm characteristics, together with election and macroeconomic variables. For the subsample of US multinationals, we have a total of 1412 observations (100 unique firms).

Our theoretical framework builds on the notion that when elections are held according to a plurality system there will be a quicker resolution of the political uncertainty surrounding the election. We validate this argument by extracting from Baker et al. (2016) the monthly-level index of economic policy uncertainty for the 22 countries available, and studying the evolution of such index in the aftermath of an election. Specifically, we estimate a regression in which the dependent variable is the logarithm of the economic policy uncertainty index, and the key explanatory variables are a set of dummies for each of the months after an election (from $t+1$ to $t+6$ ); the reference group is the month of the election. The model also includes country fixed effects to remove level differences across countries. Standard errors are heteroskedasticity-adjusted.

Figure 1 plots the regression coefficients and 5\% confidence interval estimated separately for countries with and without plurality systems. As shown, countries with plurality systems experience a significant decline in economic policy uncertainty after the election (the coefficients of the time dummies are negative and statistically different from zero). By contrast, countries without plurality system do not experience any significant decline in uncertainty. Moreover, our data indicate that countries with plurality elections form governments in half of the time as compared to countries with other electoral systems. Collectively, these results support the notion of a faster resolution of political uncertainty when elections are held with a plurality system.

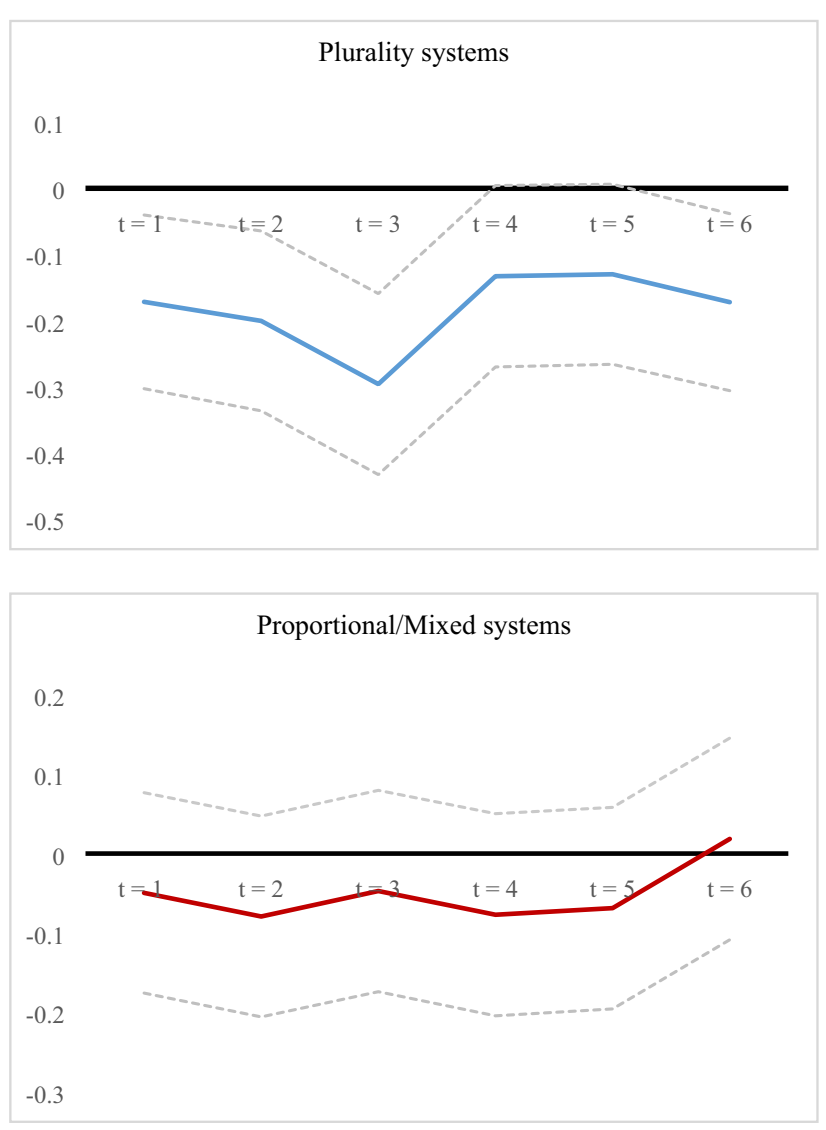

Figure 1 Evolution of economic policy uncertainty in the aftermath of elections. These figures show the coefficients of regressions (estimated separately for plurality and proportional/ mixed countries) in which the dependent variable is the logarithm of the economic policy uncertainty index (from Baker et al. 2016), and the explanatory variables are a set of dummies for each of the months after election (from $t+1$ to $t+$ $6)$; the reference group is the month of election. The regressions also include country fixed effects, and standard errors are heteroskedasticity-adjusted. The dashed lines represent the $5 \%$ confidence intervals.

In Table 3, we provide a descriptive analysis of investment activities among our sample firms. 
Table 3 Investment and political elections

\begin{tabular}{|c|c|c|c|c|c|}
\hline & Plurality & \multicolumn{3}{|c|}{ Proportional/mixed } & Difference \\
\hline \multicolumn{6}{|c|}{ Panel A: Investment by electoral systems } \\
\hline Investment & 0.0605 & \multicolumn{3}{|c|}{0.0641} & $\begin{array}{l}-0.0035 \\
(0.000)\end{array}$ \\
\hline \multicolumn{6}{|c|}{ Panel B: Investment during election periods } \\
\hline \multirow[t]{2}{*}{ Investment } & 0.0669 & \multicolumn{2}{|c|}{0.0626} & \multicolumn{2}{|r|}{$\begin{array}{l}0.0043 \\
(0.000)\end{array}$} \\
\hline & & $t=-2$ & $t=-1$ & $t=0$ & $t=1$ \\
\hline \multicolumn{6}{|c|}{ Panel C: Investment around an election } \\
\hline \multirow[t]{2}{*}{ Plurality } & Average & 0.0614 & 0.0606 & 0.0647 & 0.0592 \\
\hline & Median & 0.0301 & 0.0304 & 0.0317 & 0.0289 \\
\hline \multirow[t]{2}{*}{ Proportional/Mixed } & Average & 0.0714 & 0.0770 & 0.0709 & 0.0673 \\
\hline & Median & 0.0339 & 0.0357 & 0.0333 & 0.0323 \\
\hline
\end{tabular}

Panel A shows a $t$ test comparison of the average investment of firms in plurality or proportional/mixed systems. Panel B shows a $t$ test comparison of the average investment of firms in plurality or proportional/mixed countries during election periods. The third column of both panels shows the difference between columns 1 and 2 (with $p$ values reported in parentheses). Panel $C$ shows the average and median investment of firms in plurality or proportional/mixed systems from 2 years before to 1 year after the election period.

Results show a higher investment activity in countries with proportional or mixed systems (Panel A). Yet, once we focus on election years, we find that firms in plurality systems have a significantly higher ability to invest during election periods (Panel B). Finally, in Panel C we provide the average and median value of investment for firms in plurality or proportional/mixed electoral systems in the years around an election period. Relative to the year before the election, the investment of firms at the election year and 1 year after declines more in proportional/mixed systems than in plurality systems.

\section{EMPIRICAL ANALYSIS}

\section{Corporate Investment During Election Periods}

Consistent with our first and second hypotheses, the descriptive analysis has suggested that while corporate investment drops during elections, firms experience a different decline depending on the country's electoral system. To test this argument more thoroughly, we estimate the following regression:

$$
\begin{aligned}
I_{i j t}= & \alpha_{i}+\beta_{1} \text { Election }_{j t}+\beta_{2} \text { Plurality }_{j t}+\beta_{3} \text { Election }_{j t} \\
& \times \text { Plurality }_{j t}+\mathrm{X}_{i j t}^{\prime} \delta+\gamma_{i}+\lambda_{t}+\varepsilon_{i j t}
\end{aligned}
$$

where $i$ denotes firms, $j$ denotes countries of headquarters, and $t$ denotes years. The dependent variable is the total investment of a firm $i$ headquartered in country $j$ at time $t$. Election is a dummy equal to one in the period leading up to an election, and zero otherwise. Plurality is a dummy equal to one if the electoral system in the country of firm headquarter is based on a plurality rule, and zero otherwise (i.e., for proportional or mixed rules). The key explanatory variable is the interaction term between the dummy identifying the period leading up to an election and the plurality dummy. In accordance with our hypothesis, we expect the coefficient of this interaction term to be positive and significant.

A key feature of our empirical design is that elections do not happen at the same time across countries; this feature allows us to use as counterfactual for a firm in a country experiencing election at time $t$ another firm in a country that does not experience election at time $t$. Our regressions include firm and year $x$ industry (i.e., two-digit SIC) dummies in order to remove both constant corporate heterogeneity and industry-time effects common to all firms. To further account for timevarying differences, we include a vector $\mathbf{X}$ containing the firm-level and macroeconomic controls described in the previous section. Standard errors are clustered at the firm level.

Table 4 displays the results. Model 1 tests Hypothesis 1 without considering the interaction between elections and electoral systems. Consistent with existing works, results indicate a decline of investment during an election period: the coefficient of the election dummy (equal to 0.0008) indicates that investment drops by $1.3 \%$ from the average of 0.06 , and $2.6 \%$ from the median of 0.03 . This result gives support to Hypothesis 1 . Models 2 
Table 4 The effect of political elections and electoral systems on investment

\begin{tabular}{|c|c|c|c|c|}
\hline & $\begin{array}{l}\text { Baseline model } \\
\text { (1) }\end{array}$ & $\begin{array}{l}\text { Subsample plurality = } 1 \\
\text { (2) }\end{array}$ & $\begin{array}{l}\text { Subsample plurality }=0 \\
\text { (3) }\end{array}$ & $\begin{array}{l}\text { Interaction model } \\
\text { (4) }\end{array}$ \\
\hline \multicolumn{5}{|c|}{ Dependent variable: Investment } \\
\hline Election & $\begin{array}{l}-0.0008 \\
(0.011)\end{array}$ & $\begin{array}{l}0.0005 \\
(0.378)\end{array}$ & $\begin{array}{l}-0.0015 \\
(0.007)\end{array}$ & $\begin{array}{l}-0.0026 \\
(0.000)\end{array}$ \\
\hline Election $\times$ Plurality & & & & $\begin{array}{l}0.0034 \\
(0.000)\end{array}$ \\
\hline Plurality & $\begin{array}{l}0.0419 \\
(0.025)\end{array}$ & & & $\begin{array}{l}0.0420 \\
(0.025)\end{array}$ \\
\hline GDP growth & $\begin{array}{l}0.0011 \\
(0.000)\end{array}$ & $\begin{array}{l}0.0005 \\
(0.001)\end{array}$ & $\begin{array}{l}0.0011 \\
(0.000)\end{array}$ & $\begin{array}{l}0.0011 \\
(0.000)\end{array}$ \\
\hline Firm size & $\begin{array}{l}0.0058 \\
(0.000)\end{array}$ & $\begin{array}{l}0.0071 \\
(0.000)\end{array}$ & $\begin{array}{l}0.0051 \\
(0.000)\end{array}$ & $\begin{array}{l}0.0058 \\
(0.000)\end{array}$ \\
\hline ROA & $\begin{array}{l}-0.0175 \\
(0.000)\end{array}$ & $\begin{array}{l}-0.0253 \\
(0.000)\end{array}$ & $\begin{array}{l}0.0028 \\
(0.445)\end{array}$ & $\begin{array}{l}-0.0175 \\
(0.000)\end{array}$ \\
\hline M1 & $\begin{array}{l}-0.0000 \\
(0.012)\end{array}$ & $\begin{array}{l}0.0001 \\
(0.020)\end{array}$ & $\begin{array}{l}-0.0003 \\
(0.000)\end{array}$ & $\begin{array}{l}-0.0000 \\
(0.011)\end{array}$ \\
\hline EPU & $\begin{array}{l}-0.0238 \\
(0.000)\end{array}$ & $\begin{array}{l}-0.0122 \\
(0.000)\end{array}$ & $\begin{array}{l}-0.0239 \\
(0.000)\end{array}$ & $\begin{array}{l}-0.0235 \\
(0.000)\end{array}$ \\
\hline Interest rate & $\begin{array}{l}-0.0006 \\
(0.000)\end{array}$ & $\begin{array}{l}-0.0003 \\
(0.040)\end{array}$ & $\begin{array}{l}-0.0008 \\
(0.000)\end{array}$ & $\begin{array}{l}-0.0006 \\
(0.000)\end{array}$ \\
\hline Industry $\times$ Year effects & Yes & Yes & Yes & Yes \\
\hline Firm fixed effects & Yes & Yes & Yes & Yes \\
\hline Observations & 396,261 & 217,204 & 179,057 & 396,261 \\
\hline
\end{tabular}

$p$ values are reported in parentheses. Standard errors are clustered by firm.

and 3 estimate the regression separately on the subsamples of firms in countries with and without plurality systems. Results indicate that election periods do not significantly harm corporate investment in plurality systems, whereas the effect becomes statistically significant at the 1\% level and economically bigger (i.e., almost twice as large as the one in Model 1) in proportional or mixed countries. These findings are supportive of our second hypotheses. To offer an additional validation, we use the full sample and estimate a model that includes the interaction between elections and plurality. As shown in Model 4, the direct effect of elections remains negative and statistically significant at the 1\% level. However, the coefficient of the interaction term is positive and statistically significant at the $1 \%$ level - and similar in magnitude to the negative direct effect of elections. In other words, during electoral times, firms in countries with plurality systems invest more than their counterparts in proportional or mixed systems.

\section{Robustness and Additional Tests}

In this section, we provide a number of robustness checks to validate the results of the previous section. Results are collected in Table 5 . We start by showing (in Model 1) that our results are largely significant to clustering standard errors at the country level rather (than at the firm level, as done in the baseline analyses). This approach is useful to allow for serial correlation and heteroskedasticity by country (i.e., the level of aggregation of the election system).

Next, we move to the operationalization of the political elections. First, we show that our results are robust to using an alternative election dummy, i.e., a binary variable equal to 1 if there has been an election in a given year (at any point in time), and 0 otherwise. Results in Model 2 show that our findings remain largely unchanged. Then, we deal with the measure of electoral proportionality. As discussed in our theory development, a plurality dummy may be unable to capture the various nuances of electoral systems which generate a varying degree of proportionality in between the two polar cases of perfect plurality and proportionality. We thus re-estimate our model by replacing the plurality dummy with the Gallagher index of disproportionality (in which higher values indicate less proportionality). Model 3 shows two important results. First, the direct effect of elections on corporate investment (i.e., the effect of elections when disproportionality tends to 0 ) is negative $(p=0.06)$. This result, which is consistent with the 
Table 5 Robustness tests

\begin{tabular}{|c|c|c|c|c|c|c|c|c|c|}
\hline & $\begin{array}{l}\text { Country- } \\
\text { clustering }\end{array}$ & $\begin{array}{l}\text { Alternative } \\
\text { election } \\
\text { year }\end{array}$ & $\begin{array}{l}\text { Continuous } \\
\text { plurality }\end{array}$ & $\begin{array}{l}\text { Fixed } \\
\text { elections }\end{array}$ & $\begin{array}{l}2 S L S \\
\text { model }\end{array}$ & $\begin{array}{l}\text { Non- } \\
\text { crisis } \\
\text { years }\end{array}$ & $\begin{array}{l}\text { Only } \\
\text { elections } \\
\text { leading to } \\
\text { party } \\
\text { change } \\
\text { (7) }\end{array}$ & $\begin{array}{l}\text { Control } \\
\text { for party } \\
\text { change } \\
{[0 / 1]} \\
\text { (8) }\end{array}$ & $\begin{array}{l}\text { Control } \\
\text { for party } \\
\text { change } \\
\text { [cont.] } \\
\text { (9) }\end{array}$ \\
\hline \multicolumn{10}{|c|}{ Dependent variable: Investment } \\
\hline Election & $\begin{array}{l}-0.0026 \\
(0.000)\end{array}$ & $\begin{array}{l}-0.0018 \\
(0.000)\end{array}$ & $\begin{array}{l}-0.0011 \\
(0.064)\end{array}$ & $\begin{array}{l}-0.0033 \\
(0.078)\end{array}$ & $\begin{array}{l}-0.0299 \\
(0.000)\end{array}$ & $\begin{array}{l}-0.0020 \\
(0.000)\end{array}$ & $\begin{array}{l}-0.0217 \\
(0.000)\end{array}$ & $\begin{array}{l}-0.0028 \\
(0.000)\end{array}$ & $\begin{array}{l}-0.0018 \\
(0.001)\end{array}$ \\
\hline Election $\times$ Plurality & $\begin{array}{l}0.0034 \\
(0.005)\end{array}$ & $\begin{array}{l}0.0029 \\
(0.000)\end{array}$ & $\begin{array}{l}0.0002 \\
(0.001)\end{array}$ & $\begin{array}{l}0.0055 \\
(0.008)\end{array}$ & $\begin{array}{l}0.0312 \\
(0.000)\end{array}$ & $\begin{array}{l}0.0024 \\
(0.001)\end{array}$ & $\begin{array}{l}0.0200 \\
(0.000)\end{array}$ & $\begin{array}{l}0.0042 \\
(0.000)\end{array}$ & $\begin{array}{l}0.0041 \\
(0.001)\end{array}$ \\
\hline Plurality & $\begin{array}{l}0.0420 \\
(0.000)\end{array}$ & $\begin{array}{l}0.0417 \\
(0.026)\end{array}$ & $\begin{array}{l}0.0007 \\
(0.000)\end{array}$ & $\begin{array}{l}0.0353 \\
(0.060)\end{array}$ & $\begin{array}{l}0.0411 \\
(0.028)\end{array}$ & $\begin{array}{l}0.0364 \\
(0.498)\end{array}$ & $\begin{array}{l}0.0418 \\
(0.027)\end{array}$ & $\begin{array}{l}0.0420 \\
(0.025)\end{array}$ & \\
\hline GDP growth & $\begin{array}{l}0.0011 \\
(0.016)\end{array}$ & $\begin{array}{l}0.0011 \\
(0.000)\end{array}$ & $\begin{array}{l}0.0007 \\
(0.000)\end{array}$ & $\begin{array}{l}0.0016 \\
(0.000)\end{array}$ & $\begin{array}{l}0.0014 \\
(0.000)\end{array}$ & $\begin{array}{l}0.0011 \\
(0.000)\end{array}$ & $\begin{array}{l}0.0011 \\
(0.000)\end{array}$ & $\begin{array}{l}0.0011 \\
(0.000)\end{array}$ & $\begin{array}{l}0.0008 \\
(0.000)\end{array}$ \\
\hline Firm size & $\begin{array}{l}0.0058 \\
(0.000)\end{array}$ & $\begin{array}{l}0.0058 \\
(0.000)\end{array}$ & $\begin{array}{l}0.0058 \\
(0.000)\end{array}$ & $\begin{array}{l}0.0061 \\
(0.000)\end{array}$ & $\begin{array}{l}0.0059 \\
(0.000)\end{array}$ & $\begin{array}{l}0.0058 \\
(0.000)\end{array}$ & $\begin{array}{l}0.0051 \\
(0.000)\end{array}$ & $\begin{array}{l}0.0058 \\
(0.000)\end{array}$ & $\begin{array}{l}0.0078 \\
(0.000)\end{array}$ \\
\hline ROA & $\begin{array}{l}-0.0175 \\
(0.092)\end{array}$ & $\begin{array}{l}-0.0175 \\
(0.000)\end{array}$ & $\begin{array}{l}-0.0222 \\
(0.000)\end{array}$ & $\begin{array}{l}-0.0262 \\
(0.000)\end{array}$ & $\begin{array}{l}-0.0176 \\
(0.000)\end{array}$ & $\begin{array}{l}-0.0190 \\
(0.000)\end{array}$ & $\begin{array}{l}-0.0143 \\
(0.000)\end{array}$ & $\begin{array}{l}-0.0175 \\
(0.000)\end{array}$ & $\begin{array}{l}-0.0256 \\
(0.000)\end{array}$ \\
\hline M1 & $\begin{array}{l}-0.0000 \\
(0.531)\end{array}$ & $\begin{array}{l}-0.0000 \\
(0.008)\end{array}$ & $\begin{array}{l}-0.0001 \\
(0.000)\end{array}$ & $\begin{array}{l}0.0000 \\
(0.518)\end{array}$ & $\begin{array}{l}-0.0000 \\
(0.091)\end{array}$ & $\begin{array}{l}-0.0000 \\
(0.023)\end{array}$ & $\begin{array}{l}-0.0001 \\
(0.003)\end{array}$ & $\begin{array}{l}-0.0000 \\
(0.009)\end{array}$ & $\begin{array}{l}-0.0001 \\
(0.001)\end{array}$ \\
\hline EPU & $\begin{array}{l}-0.0235 \\
(0.022)\end{array}$ & $\begin{array}{l}-0.0234 \\
(0.000)\end{array}$ & $\begin{array}{l}-0.0184 \\
(0.000)\end{array}$ & $\begin{array}{l}-0.0040 \\
(0.221)\end{array}$ & $\begin{array}{l}-0.0226 \\
(0.000)\end{array}$ & $\begin{array}{l}-0.0201 \\
(0.000)\end{array}$ & $\begin{array}{l}-0.0211 \\
(0.000)\end{array}$ & $\begin{array}{l}-0.0233 \\
(0.000)\end{array}$ & $\begin{array}{l}-0.0047 \\
(0.079)\end{array}$ \\
\hline Interest rate & $\begin{array}{l}-0.0006 \\
(0.092)\end{array}$ & $\begin{array}{l}-0.0006 \\
(0.000)\end{array}$ & $\begin{array}{l}-0.0005 \\
(0.000)\end{array}$ & $\begin{array}{l}-0.0001 \\
(0.621)\end{array}$ & $\begin{array}{l}-0.0004 \\
(0.000)\end{array}$ & $\begin{array}{l}-0.0007 \\
(0.000)\end{array}$ & $\begin{array}{l}-0.0006 \\
(0.000)\end{array}$ & $\begin{array}{l}-0.0006 \\
(0.000)\end{array}$ & $\begin{array}{l}-0.0000 \\
(0.857)\end{array}$ \\
\hline Party change & & & & & & & & $\begin{array}{l}-0.0023 \\
(0.000)\end{array}$ & $\begin{array}{l}0.0000 \\
(0.805)\end{array}$ \\
\hline $\begin{array}{l}\text { Industry } \times \text { Year } \\
\text { effects }\end{array}$ & Yes & Yes & Yes & Yes & Yes & Yes & Yes & Yes & Yes \\
\hline Firm fixed effects & Yes & Yes & Yes & Yes & Yes & Yes & Yes & Yes & Yes \\
\hline Observations & 396,261 & 396,261 & 352,527 & 170,658 & 396,261 & 347,318 & 326,149 & 396,261 & 161,531 \\
\hline
\end{tabular}

$p$ values are reported in parentheses. Unless differently specified, standard errors are clustered by firm.

direct effect of the election dummy in Model 4 of Table 4, shows that elections harm firms' investment in proportional countries. Second, the coefficient of the interaction term is positive, and thus denotes that an increase in disproportionality reduces the negative effect of elections on investment. Economically, a standard deviation increase in disproportionality reduces almost entirely the negative direct effect of elections on investment. To probe more into this result, we provide a graphical illustration using the method described in Meyer et al. (2017). Figure 2 plots the marginal effect of elections on investment over the full range of values of electoral disproportionality. Each dot represents all observations for each value of disproportionality in the sample, and the two lines represent the $95 \%$ confidence intervals. As shown, the effect of elections on investment is negative for a range of values in the low end of the proportionality distribution (the vertical lines represent the bottom and top quartile of electoral disproportionality); however, the effect becomes less negative as disproportionality increases. The effect of elections turns even positive when disproportionality reaches very high levels (i.e., closer to the top decile). ${ }^{12}$ Our hypothesis is thus supported for the vast majority of sample firms. However, in the Discussion section we will discuss this latter unexpected finding.

Next, we deal with concerns of endogeneity in the timing of elections. A number of countries in our sample have a flexible schedule of elections, i.e., elections may be called upon before the natural expiry of a government. This, in turn, raises the concern that the timing of elections can be endogenous to events, such as the deterioration of economic performance or political turmoil, which can also affect firms' investment. Our baseline regressions do control for several variables capturing a country's economic performance. However, 


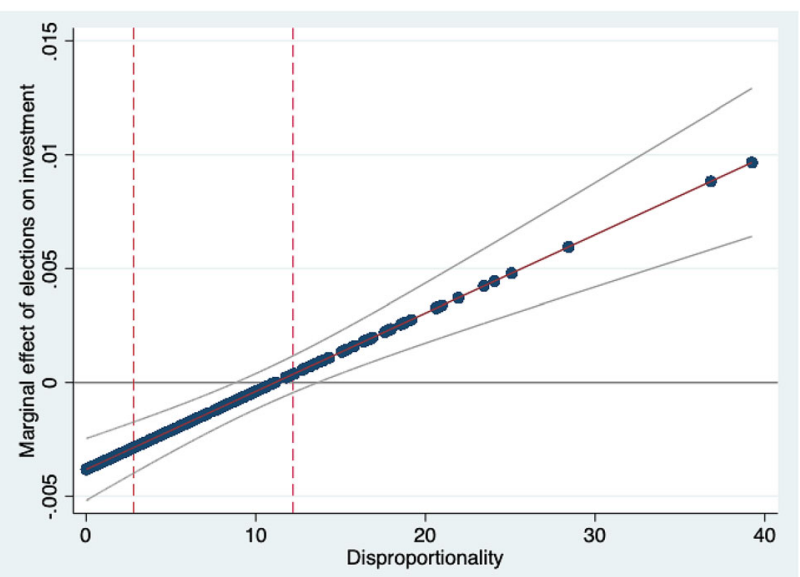

Figure 2 Effect of elections on corporate investment for different values of disproportionality. This graph illustrates the result in Model 3 of Table 5 by plotting the marginal effect of elections on investment over the full range of values of electoral disproportionality. Each dot represents all observations for each value of disproportionality in the sample, and the two surrounding lines represent the $95 \%$ confidence intervals. The dashed vertical lines represent the values of the bottom and top quartile of electoral disproportionality.

to further rule out this concern, we conduct the analysis excluding countries with a flexible election schedule. Our results, shown in Model 4 of Table 5, are unaffected by this restriction. ${ }^{13}$ Additionally, we follow existing approaches based on the use of pre-determined election schedules as an instrument for the observed election cycle (Alok \& Ayyagari, 2020; Durnev, 2011). Election schedules are defined as the official timespan between elections: they are a strong predictor of the actual occurrence of an election (which satisfies the relevance condition) and plausibly have no bearing on firm investment other than through the timing of the actual election (which satisfies the exclusion restriction). To construct election schedules, we hand-collect data on the length of time between elections for every country in our sample. Second-stage results of the 2SLS regression (reported in Model 5) indicate that our results remain statistically significant and become larger in terms of economic magnitude. ${ }^{14}$

All our regressions control for the interaction between year and industry dummies, which are useful to absorb time effects (e.g., due to global business cycles) that are also heterogeneous across industries. Yet, one may be concerned that some factors, such as the recent financial crisis, affected countries in a way that may confound our results. To alleviate this concern, we re-estimated our models excluding the years of banking crises (drawn from Laeven \& Valencia, 2018). Results reported in Model 6 are again consistent with our baseline findings. ${ }^{15}$

In number of additional checks, we account for the role of abrupt changes in government policies across electoral systems. One may argue that coalition governments (more frequent in proportional systems) create some continuity in government policies, which in turn reduces the spike in uncertainty during an election. The Database of Political Institutions contains a classification of the ruling party's orientation (i.e., left, center or right) with regard to economic and social policies. We collect data on the political orientation of the ruling government to check whether changes in political views (from left to right or vice versa) are more common in proportional or plurality systems. We then re-estimate our model by using election periods that led to a drastic change in government. As expected, results in Model 7 show that the effect of elections on investment is significant and economically larger than our baseline estimates. Yet, the coefficient of the interaction term with plurality remains statistically and economically significant. Alternatively, we control for a dummy equal to 1 for changes in political views. Results in Model 8 indicate that, while a change in political views has a negative effect on firms' investment, the positive interaction effect of plurality and elections remains significant. Moreover, our results are robust to employing a continuous control for changes in party ideology. To this end, we use the Parliaments and Governments (ParlGov) database which (for a subsample of country-years) contains a variable which measures the ruling party's left/right orientation on a scale from 0 to 10 . Using this variable, we construct a continuous variable by taking the squared of the change in the ruling party's orientation. Our findings, reported in Model 9 , are robust to this alternative operationalization (notice that here it is not possible to estimate the direct effect of plurality because this variable does not exhibit time changes in the sample used in this regression, and is thus perfectly collinear with firm fixed effects).

A key mechanism through which plurality systems may reduce uncertainty surrounding an election is that they allow a timelier appointment of the ruling government. This, in turn, helps to resolve the uncertainty about the future policies that will be implemented. To validate this argument, we estimate a model in which the key 
explanatory variable is (for each legislature) the log of the timespan (in days) between elections and government formation (drawn from ParlGov). Results (reported in "Appendix 1" section) indicate that a slower appointment of the new government is negatively associated with firms' investment. This finding provides some direct support to one of the mechanisms outlined in the theoretical section.

Our election dummy is designed to capture changes in investment occurring in the period leading up to an election. A related question concerns the investment activity in the aftermath of an election. To explore this issue, we compute a post-election dummy equal to one for the year subsequent to an election period. We then estimate separately the model for firms in plurality or proportional/mixed electoral systems. Results in "Appendix 2" section indicate that the coefficient of the post-election dummy is not significant for firms in plurality systems (Model 1), whereas it is negative and significant for firms in countries with proportional/mixed systems (Model 2). This result is consistent with the intuition that proportionality lengthens the negative effect of electoral cycles on corporate investment.

\section{Investment Behavior of Multinationals During Foreign Elections}

In this section, we test the third and fourth hypotheses, which concern the sensitivity of multinationals' foreign investment to political elections in the host countries. To this end, we use a subsample of Compustat US-listed firms (from 1998 to 2017) which disclose investment data relative to the foreign countries where they operate. We estimate the following model:

$$
\begin{aligned}
I_{i j t}= & \alpha_{i}+\beta_{1} \text { Foreign Election }_{j t}+\beta_{2} \text { Plurality }_{i t} \\
& +\beta_{3} \text { Foreign Election }_{j t} \times \text { Plurality }_{i t}+\mathrm{X}_{i j t}^{\prime} \delta+\gamma_{i} \\
& +\lambda_{t}+\varepsilon_{i j t}
\end{aligned}
$$

where the dependent variable is the foreign investment of multinational $i$ in country $j$ at time $t$ (i.e., capital expenditures in the foreign country scaled by the beginning-of-year book value of foreign total assets). The electoral explanatory variables are operationalized as in our previous analyses, but at the level of the host country. ${ }^{16}$ Our hypotheses suggest that elections in a host country have a negative effect on the multinational's foreign investment in that country; however, when such elections are held according to a plurality rule the negative effect is attenuated (i.e., the interaction term is expected to have a positive coefficient).

Table 6 displays the results. Model 1 shows the results obtained by clustering standard errors at the firm level. Consistent with our hypotheses, elections in the host country have a negative and significant effect on multinationals' foreign investment. Moreover, the coefficient of the interaction term between foreign elections and plurality is positive and statistically significant. In other words, during elections, multinational firms in countries with a plurality system invest more than multinationals in countries with other systems. These results support the third and fourth hypotheses of our study. In Model 2, we show the robustness to clustering residuals at the country level, whereas in Model 3 we show the results obtained by replacing the plurality dummy with the continuous measure of electoral disproportionality. Economically, a standard deviation increase in disproportionality reduces by $60 \%$ the direct negative effect of elections on foreign investment.

\section{DISCUSSION}

Politics can significantly shape a firm's access to resources and ultimately its financial profitability (Hillman \& Hitt, 1999). Drawing on insights from institutional economics (North, 1990), the literature has devoted much attention to the relationship between a country's political characteristics and firms' strategies (e.g., Henisz \& Delios, 2001; Murtha \& Lenway, 1994; Soule et al. 2014). Within this research inquiry, one political factor that has lately received significant attention is political uncertainty. Government actions encompass several dimensions related to trade policies, regulation, procurement contracts, and taxation, which are all relevant for corporate activities. Political uncertainty relates to the difficulty of firms to forecast such actions or gather key information on the legislative process (Julio \& Yook, 2012).

Political uncertainty tends to naturally rise during times of election, whose fate is often unexpected and may thus delay the decision of firms to invest in irreversible projects. Building on this idea, a recent literature has suggested to leverage the electoral cycle to capture variations in political uncertainty over time. Works in this area show that during electoral periods, at both the national and local level, firms significantly reduce their investment activities (Amore \& Minichilli, 2018; Jens, 2017; Julio \& Yook, 2012, 2016). 
Table 6 Effect of foreign political elections and electoral systems on foreign investment

\begin{tabular}{|c|c|c|c|}
\hline & $\begin{array}{l}\text { Interaction model } \\
\text { (1) }\end{array}$ & $\begin{array}{l}\text { Country-clustering } \\
\text { (2) }\end{array}$ & $\begin{array}{l}\text { Continuous plurality } \\
\text { (3) }\end{array}$ \\
\hline \multicolumn{4}{|c|}{ Dependent variable: Foreign investment } \\
\hline \multirow[t]{2}{*}{ Foreign election } & -0.0333 & -0.0333 & -0.0626 \\
\hline & $(0.026)$ & $(0.032)$ & $(0.010)$ \\
\hline \multirow[t]{2}{*}{ Foreign election $\times$ Plurality } & 0.0376 & 0.0376 & 0.0041 \\
\hline & $(0.047)$ & $(0.015)$ & $(0.009)$ \\
\hline \multirow[t]{2}{*}{ Plurality } & -0.0100 & -0.0100 & -0.0009 \\
\hline & $(0.346)$ & $(0.130)$ & $(0.037)$ \\
\hline \multirow[t]{2}{*}{ GDP growth } & 0.0020 & 0.0020 & 0.0021 \\
\hline & $(0.297)$ & $(0.134)$ & $(0.295)$ \\
\hline \multirow[t]{2}{*}{ Firm size } & -0.0010 & -0.0010 & -0.0010 \\
\hline & $(0.893)$ & $(0.888)$ & $(0.897)$ \\
\hline \multirow[t]{2}{*}{ M1 } & 0.0000 & 0.0000 & 0.0000 \\
\hline & $(0.832)$ & $(0.780)$ & $(0.742)$ \\
\hline \multirow[t]{2}{*}{ EPU } & -0.0106 & -0.0106 & -0.0067 \\
\hline & $(0.674)$ & $(0.585)$ & $(0.742)$ \\
\hline \multirow[t]{2}{*}{ Interest rate } & 0.0002 & 0.0002 & 0.0002 \\
\hline & $(0.530)$ & $(0.144)$ & $(0.657)$ \\
\hline Industry $\times$ Year effects & Yes & Yes & Yes \\
\hline Firm fixed effects & Yes & Yes & Yes \\
\hline Observations & 1412 & 1412 & 1337 \\
\hline
\end{tabular}

$p$ values are reported in parentheses. Unless differently specified, standard errors are clustered by firm.

We contributed to this literature in two significant directions. First, we expanded existing evidence on the relationship between electoral cycles and corporate investment by examining an important yet underexplored aspect of a country's political institutions, i.e., the electoral system. As we argued, in plurality systems voting results map more directly into parliamentary seats and hence policy outcomes, the prediction over future policy outcomes is more straightforward, and the new government is typically appointed soon after the voting date. These features contribute to attenuate the amount of political uncertainty that firms face in the wake of an election. Second, we analyzed the relationship between multinationality and political uncertainty in a firm's host country. Our arguments have suggested that while multinationals may be well equipped to hedge political risk in their home country, their international activities make them sensitive to foreign countries' electoral cycles and their election system. By ascertaining the effect of foreign election cycles on multinationals, we offer a relevant contribution to the literature on how political risk influences foreign direct investment (e.g., Azzimonti, 2019; Beazer \& Blake, 2018; Julio \& Yook, 2012; Jensen, 2008; Liu \& Li 2020) and, more generally, on the role of institutions in international business (e.g., Hoskisson et al. 2013).
We conducted the empirical analyses on two samples: a global dataset of listed firms from 1991 to 2017 , and a sample of US listed multinationals from 1998 to 2017. A key empirical advantage of our analysis is that elections are held at different points in time across countries, and thus we can control for common effects to all sample firms. Moreover, electoral systems display significant differences across countries while being relatively exogenous to corporate outcomes. Consistent with our hypotheses, the evidence indicates that firms operating in countries with a plurality system are significantly better able to invest during election periods. Additionally, we find that the foreign investment of US multinational firms declines during elections in the foreign countries where these such firms operate. Yet, plurality systems appear to ameliorate such effect: the decline in foreign investment by US multinationals is lower when the foreign elections are held according to a plurality system.

By studying the propagation of political shocks on firm activities across different political environments, our findings help to grasp the institutional nuances connotating the relationship between political uncertainty and corporate outcomes. Moreover, they provide guidance to executives that need to confront the vicious implications of 
political uncertainty for their geographic expansion activities. The literature in this realm has already remarked the importance of political uncertainty for foreign investment (Julio \& Yook, 2016; Nguyen et al. 2018). Our work suggests to beware of a specific element of a country's set of political institution, i.e., the electoral formula according to which the elections are held. To the extent to which elections do not take place simultaneously across countries, taking into consideration the electoral system of the host countries represents an opportunity toward developing portfolios of foreign investments that are more resilient to political shocks.

Our work has a number of limitations, which also provide opportunities for future research. The first relates to the challenge of measuring foreign investment with accounting data. This approach is common to the international business literature, which has benefited from a general improvement in the quality of accounting information following the adoption of rules like SFAS 131. That said, quantifying foreign investment using accounting data on the amount of capital investment may be subject to opaqueness and discretionary disclosure. Additionally, this approach typically involves annual data, which may not be ideal to capture adjustments in investment that may occur within an electoral cycle. Having fine-grained data on capital allocation over shorter periods of time can enhance our understanding of the relationship between electoral cycles and firms' strategies. This approach could also shed light on an unexpected finding of our analysis, i.e., that the effect of elections on investment turns positive for a small subset of firms subject to very high disproportionality. Recent works show that firms can time investment decisions along the political cycle to pursue political objectives. For instance, stateowned firms have been shown to increase investment and employment during election times as a means to construct voter support (Alok \& Ayyagari, 2020; Inoue, 2020). Going beyond state-owned firms, there is evidence that firms with social ties with politics increase employment during an election to support incumbent politicians (Bertrand et al. 2018). If these corporate actions are made to derive benefits from a social exchange with politicians, they might to be stronger in plurality singlemember districts, where politicians can undertake distributive policies with more concentrated benefits. Studying how the relationships between politicians and firms differ depending on the electoral system provides a fruitful area of future research.

Another limitation of our study concerns the operationalization of multinational firms and their foreign investment activities. Due to data constraints, we limited the analysis to US-listed multinationals with usable data in the Compustat Geographic Segment file. Future studies can expand the analysis by using broader samples of multinationals from multiple countries. Finally, we wish to address endogeneity issues regarding a country's elections. It is well known that electoral systems are largely time-invariant, and thus mostly unaffected by (current) business outcomes. Endogeneity in the timing of (early) elections is subtler as it can arise from a wealth of unobservable factors related to a country's economic and political conditions. To reduce this concern, we have followed existing prescriptions about including macroeconomic controls, checking the robustness to the use of fixed election schedules, and employing an instrumental variable regression. Future studies can account more explicitly for the nuances of the processes that may lead to early elections by also employing data on the political agendas of parties involved in the election and the intensity of electoral competition.

\section{ACKNOWLEDGEMENTS}

For useful comments and suggestions, we thank two anonymous reviewers, and Arjen van Witteloostuijn, Alvaro Cuervo-Cazurra, Riccardo Marzano, Alessandro Minichilli, Ram Mudambi, Torben Petersen, as well as conference participants at the Academy of International Business PDW (2020), the Strategic Management Society (2020), and the Study Days Workshop at Bocconi University (2019).

\section{FUNDING}

Open access funding provided by Università Commerciale Luigi Bocconi within the CRUI-CARE Agreement.

\section{NOTES}

${ }^{1} \mathrm{~A}$ mechanism at play goes back to Bernanke (1983) and Wernerfelt and Karnani (1987), who suggested that when uncertainty increases, the realoption value of waiting to invest in irreversible projects increases. Another explanation is that 
policy uncertainty is difficult to be diversified away, and thus increases financing costs (Pastor \& Veronesi, 2012).

${ }^{2}$ For instance, Rae (1967) shows that a unit increase in the vote share increases the seat share by 1.07 in proportional systems and 1.20 in plurality systems.

${ }^{3} \mathrm{~A}$ survey of 20 countries found that $56 \%$ of elections with plurality systems produced singleparty governments, as compared with $36 \%$ of elections with mixed systems, and $34 \%$ with proportional systems (Blais \& Carty, 1987).

${ }^{4} \mathrm{~A}$ specific source of uncertainty stemming from proportional systems relates to fiscal policies. Persson et al. (2003) show that coalition governments appointed with proportional rules tend to increase fiscal deficits (hence potentially raising uncertainty over future government actions). Along this line, Alesina and Perotti (1995) argue that "conflicts amongst coalition members and the fragility of coalition governments make it difficult to maintain a 'tough' fiscal stance, particularly when politically sensitive programs, government employment and social security are involved." Fiscal uncertainty is a major element of the economic policy uncertainty index developed by Baker et al. (2016), which is in turn negatively associated with firms' investment (Gulen \& Ion, 2016).

${ }^{5}$ Another argument relates to the flexibility and bargaining power that result from a multinational network and from broader economies of scale, scope, and learning (Kogut, 1985). A global network can enable firms to reallocate investment away from host countries where uncertainty surges (Kogut \& Kulatilaka, 1994). Multinationality also grants flexibility options useful to minimize uncertainty (De Meza \& Van der Ploeg, 1987; Kogut, 1985; Kogut \& Kulatilaka, 1994).

${ }^{6}$ To provide an example, consider the US elections in 2016, which were held on November 6th. $70 \%$ of US sample firms in 2016 ended the fiscal year on December 31st. For them, 2016 would be an election year. In fact, 2016 would be election year for fiscal year ends from March onward (97\% of all US firms).

${ }^{7}$ Electoral systems are notoriously stable over time. Some countries like the US, UK, and Canada have always had the same system. During the 1990s, electoral reforms took place in Japan and New Zealand, which moved to a mixed system.
${ }^{8}$ Unfortunately, we do not have data to distinguish multinationals and single-country firms in the global dataset employed for testing the first two hypotheses. Our analysis based on Compustat Geographic Segment data starts in 1998 because this is the year when the Statement of Financial Accounting Standards (SFAS) 131 went into effect. SFAS 131 introduced significant changes to the disclosure of company's foreign operations, which raised data reliability and facilitated the pricing of foreign earnings (Hope et al. 2009).

${ }^{9}$ We use a parsimonious set of controls to avoid missing values. However, in untabulated regressions we check that our results are robust to using additional controls such as a firm's cash flows, the debt-to-equity ratio, and the ratio of cash holdings to total assets. Also, our results are robust to only controlling for year dummies rather than the interaction between year and industry dummies.

${ }^{10}$ Values come from Baker et al. (2016), which develops an index that quantifies economic policy uncertainty around the world using the scaled count of words in major newspaper articles containing keywords related to: (1) uncertainty; (2) policy; and (3) the economy. See https://www. policyuncertainty.com for more details. Baker et al. (2016) validated this index by showing its association with other measures of uncertainty, e.g., implied stock market volatility.

${ }^{11}$ In untabulated tests we check the robustness to controlling for the degree of central bank independence (Cukierman et al. 1992).

${ }^{12}$ In a supplementary test, we augmented the model with the quadratic term of disproportionality and its interaction with the election dummy. The quadratic terms did not display any significance.

${ }^{13}$ This result is consistent with Julio and Yook (2012) which documents a negative effect of elections on firms' investment in both countries with flexible and fixed election schedules.

${ }^{14}$ The instrument is statistically significant in the first stage and that the F-statistic of the first stage is above the conventional thresholds used to detect weak-instrument problems.

${ }^{15}$ Our results are also robust to excluding the early years (such as the first three) or late years (such as the last three) of our panel dataset.

${ }^{16} \mathrm{Among}$ the firm-level controls, we only include firm size since other items display a large number of missing values. 


\section{REFERENCES}

Alesina, A., Ozler, S., Roubini, N., \& Swagel, P. 1996. Political instability and economic growth. Journal of Economic Growth, 1: 189-211.

Alok, S., \& Ayyagari, M. 2020. Politics, state ownership, and corporate investment. Review of Financial Studies, 33: 3031-3087.

Amore, M. D. 2020. Innovation disclosure in times of uncertainty. Journal of Economics and Management Strategy, 29: 792-815.

Amore, M. D., \& Bennedsen, M. 2013. The value of local political connections in a low-corruption environment. Journal of Financial Economics, 110: 387-402.

Amore, M. D., \& Minichilli, A. 2018. Local political uncertainty, family control and investment behavior. Journal of Financial and Quantitative Analysis, 53: 1781-1804.

Azzimonti, M. 2019. Does political conflict deter FDI inflows to the US? Journal of International Economics, 120: 162-178.

Baker, S. R., Bloom, N., \& Davis, S. J. 2016. Measuring economic policy uncertainty. Quarterly Journal of Economics, 131: 1593-1636.

Barkema, H., Bell, J., \& Pennings, J. 1996. Foreign entry, cultural barriers, and learning. Strategic Management Journal, 17: 151-166.

Beazer, Q. H., \& Blake, D. J. 2018. The conditional nature of political risk: How home institutions influence the location of Foreign Direct Investment. American Journal of Political Science, 62(2): 470-485.

Beckman, C., Haunschild, P., \& Phillips, D. 2004. Friends or strangers? Firm-specific uncertainty, market uncertainty, and network partner selection. Organization Science, 15: 259-327.

Bennett, V., \& Hall, T. 2020. Software availability and entry. Strategic Management Journal, 41: 950-962.

Bernanke, B. S. 1983. Irreversibility, uncertainty, and cyclical investment. NBER Working Paper No. 502.

Bertrand, M., Kramarz, F., Schoar, A., \& Thesmar, D. 2018. The cost of political connections. Review of Finance, 22: 849-876.

Blais, A., \& Carty, K. 1987. The impact of electoral formulae on the creation of majority governments. Electoral Studies, 6: 209-218.

Blais, A., \& Massicotte, L. 1997. Electoral formulas: A macroscopic perspective. European Journal of Political Research, 32: 107-129.

Blake, D., \& Jandhyala, S. 2019. Managing policy reversals: Consequences for firm performance. Strategy Science, 4: 61-174.

Bloom, N. 2014. Fluctuations in uncertainty. Journal of Economic Perspectives, 28: 153-176.

Bode, C., Wagner, S., Petersen, K., \& Ellram, L. 2011. Understanding responses to supply chain disruptions: Insights from information processing and resource dependence perspectives. Academy of Management Journal, 54: 833-856.

Bonaime, A., Gulen, H., \& Ion, M. 2018. Does policy uncertainty affect mergers and acquisitions? Journal of Financial Economics, 129: $531-558$.

Bormann, N. C., \& Golder, M. 2013. Democratic electoral systems around the world, 1946-2011. Electoral Studies, 32: 360-369.

Brogaard, J., \& Detzel, A. 2015. The asset-pricing implications of government economic policy uncertainty. Management Science, 61: 3-18.

Brown, L. W., Yasar, M., \& Rasheed, A. A. 2018. Predictors of foreign corporate political activities in United States politics. Global Strategy Journal, 8: 503-514.

Carey, J. M., \& Hix, S. 2011. The electoral sweet spot: Lowmagnitude proportional electoral systems. American Journal of Political Science, 55: 383-397.

Carroll, G. R., Delacroix, J., \& Goldstein, J. 1988. The political environments of organizations: An ecological view. Research in Organizational Behavior, 10: 359-392.
Carson, S. J., Madhok, A., \& Wu, T. 2006. Uncertainty, opportunism, and governance: The effects of volatility and ambiguity on formal and relational contracting. Academy of Management Journal, 49: 1058-1077.

Chakrabarti, A. 2014. Organizational adaptation in an economic shock: The role of growth reconfiguration. Strategic Management Journal, 36: 1717-1738.

Chan, C., Makino, S., \& Isobe, T. 2010. Does subnational region matter? Foreign affiliate performance in the US and China. Strategic Management Journal, 31: 1226-1243.

Chang, S., Zhigang, T., Hongjie, Y., \& Hongyong, Z. 2019. The impact of the US-China trade war on Japanese multinational corporations. Working Paper.

Choy, H., Gul, F., \& Yao, J. 2011. Does political economy reduce agency costs? Some evidence from dividend policies around the world. Journal of Empirical Finance, 18: 16-35.

Colak, G., Durnev, A., \& Qian, Y. 2017. Political uncertainty and IPO activity: Evidence from U.S. gubernatorial elections. Journal of Financial and Quantitative Analysis, 52: 2523-2564.

Courtney, H., Kirkland, J., \& Viguerie, P. 1997. Strategy under uncertainty. Harvard Business Review, 75: 67-79.

Cruz, C., Keefer, P., \& Scartascini, C. 2018. Database of political institutions. Inter-American Development Bank.

Cukierman, A., Webb, S. B., \& Neyapti, B. 1992. Measuring the independence of central banks and its effect on policy outcomes. World Bank Economic Review, 6(353): 398.

Cumming, D., \& Zahra, S. 2016. International business and entrepreneurship implications of Brexit. British Journal of Management, 27: 687-692.

Dangl, T., \& Wu, Y. 2016. Corporate investment over the business cycle. Review of Finance, 20: 337-371.

Daniels, J. D., \& Bracker, J. 1989. Profit performance: Do foreign operations make a difference? Management International Review, 29: 46.

Davis, S. J. 2019. Rising policy uncertainty. Hoover Institution Working Paper No. 19110.

De Meza, D., \& Van der Ploeg, F. 1987. Production flexibility as a motive for multinationality. Journal of Industrial Economics, 35: 343-352.

Delios, A., \& Henisz, W. J. 2003. Political hazards, experience, and sequential entry strategies: The international expansion of Japanese firms, 1980-1998. Strategic Management Journal, 24: 1153-1164.

Denis, D., Denis, D., \& Yost, K. 2002. Global diversification, industrial diversification, and firm value. Journal of Finance, 57: 1951-1979.

Dhingra, S., Ottaviano, G., Sampson, T., \& Van Reenen, J. 2016. The consequences of Brexit for UK trade and living standards. Centre for Economic Performance.

Dow, J. 2001. A comparative spatial analysis of majoritarian and proportional elections. Electoral Studies, 20: 109-125.

Driffield, N., \& Love, J. 2007. Linking FDI motivation and host economy productivity effects: Conceptual and empirical analysis. Journal of International Business Studies, 38: 460-473.

Dunning, J. H. 1981. International production and the multinational enterprise. Allen and Unwin.

Durnev, A. 2011. The real effects of political uncertainty: Elections and investment sensitivity to stock prices. Working Paper.

Duru, A., \& Reeb, D. 2002. International diversification and analysts forecast accuracy and bias. The Accounting Review, 77: 415-433.

Dutt, N., \& Joseph, J. 2019. Regulatory uncertainty, corporate structure, and strategic agendas: Evidence from the U.S. renewable electricity industry. Academy of Management Journal, 62: 800-827.

Fabrizio, K. 2013. The effect of regulatory uncertainty on investment: Evidence from renewable energy generation. Journal of Law, Economics and Organization, 29: 765-798. 
Faeth, I. 2009. Determinants of foreign direct investment: A tale of nine theoretical models. Journal of Economic Surveys, 23: 165-196.

Filippaios, F., Annan-Diab, F., Hermidas, A., \& Theodoraki, C. 2019. Political governance, civil liberties, and human capital: Evaluating their effect on foreign direct investment in emerging and developing economies. Journal of International Business Studies, 50: 1103-1129.

Gaba, V., \& Terlaak, A. 2013. Decomposing uncertainty and its effects on imitation in firm exit decisions. Organization Science, 24: 1-23.

Gallagher, M. 1991. Proportionality, disproportionality and electoral systems. Electoral Studies, 10: 33-51.

Gertler, M., \& Gilchrist, S. 1994. Monetary policy, business cycles, and the behavior of small manufacturing firms. Quarterly Journal of Economics, 108: 309-340.

Giambona, E., Graham, J., \& Harvey, C. 2017. The management of political risk. Journal of International Business Studies, 48: 523-533.

Grant, M. R. 1987. Multinationality and performance among British manufacturing companies. Journal of International Business Studies, 18: 79-89.

Greve, H. R. 1996. Patterns of competition: The diffusion of a market position in radio broadcasting. Administrative Science Quarterly, 41: 29-61.

Gulen, H., \& Ion, M. 2016. Policy uncertainty and corporate investment. Review of Financial Studies, 29: 523-564.

Haunschild, P. R. 1994. How much is that company worth? Interorganizational relationships, uncertainty, and acquisition premiums. Administrative Science Quarterly, 39: 391-411.

Henisz, W. J. 2000. The institutional environment for multinational investment. Journal of Law, Economics, and Organization, 16: 334-364.

Henisz, W. J., \& Delios, A. 2001. Uncertainty, imitation, and plant location: Japanese multinational corporations, 1990-1996. Administrative Science Quarterly, 46: 443-475.

Hill, P., Korczak, A., \& Korczak, P. 2019. Political uncertainty exposure of individual companies: The case of Brexit. Journal of Banking \& Finance, 100: 58-76.

Hillman, A. J., \& Hitt, M. A. 1999. Corporate political strategy formulation: A model of approach, participation, and strategy decisions. Academy of Management Review, 24: 825-842.

Hitt, M. A., Tihanyi, L., Miller, T., \& Connelly, B. 2006. International diversification: Antecedents, outcomes, and moderators. Journal of Management, 32: 831-867.

Holburn, G., \& Zelner, B. 2010. Political capabilities, policy risk, and international investment strategy: Evidence from the global electric power generation industry. Strategic Management Journal, 31: 1290-1315.

Hope, O. K., Kang, T., Thomas, W., \& Vasvari, F. 2009. The effects of SFAS 131 geographic segment disclosures by US multinational companies on the valuation of foreign earnings. Journal of International Business Studies, 40: 421-443.

Hoskisson, R., Wright, M., Filatotchev, I., \& Peng, M. 2013. Emerging multinationals from mid-range economies: The influence of institutions and factor markets. Journal of Management Studies, 50: 1295-1321.

Hout, E., \& McGann, A. J. 2009. Liberal political equality implies proportional representation. Social Choice and Welfare, 33: 617-627.

Huang, T., Wu, F., Yu, J., \& Zhang, B. 2015. Political risk and dividend policy: Evidence from international political crises. Journal of International Business Studies, 46: 574-595.

Indridason, I. 2011. Proportional representation, majoritarian legislatures, and coalitional voting. American Journal of Political Science, 55: 955-971.
Inoue, C. 2020. Election cycles and organizations: How politics shapes the performance of state-owned enterprises over time. Administrative Science Quarterly, 65: 677-709.

James, B. E., \& Vaaler, P. M. 2018. Minority rules: Credible state ownership and investment risk around the world. Organization Science, 29: 4.

Jens, C. E. 2017. Political uncertainty and investment: Causal evidence from U.S. gubernatorial elections. Journal of Financial Economics, 124: 563-579.

Jensen, N. 2008. Political risk, democratic institutions, and foreign direct investment. Journal of Politics, 70: 1040-1052.

Johanson, J., \& Vahlne, J. E. 1977. The internationalization process of the firm: A model of knowledge development and increasing foreign market commitments. Journal of International Business Studies, 8: 23-32.

Jorion, P. 1990. The exchange-rate exposure of US multinationals. Journal of Business, 63: 331-345.

Julio, B., \& Yook, Y. 2012. Political uncertainty and corporate investment cycles. Journal of Finance, 67: 45-83.

Julio, B., \& Yook, Y. 2016. Policy uncertainty, irreversibility, and cross-border flows of capital. Journal of International Economics, 103: 13-26.

Kim, W. C., Hwang, P., \& Burgers, W. P. 1993. Multinationals' diversification and the risk-return trade-off. Strategic Management Journal, 14: 275-286.

Kingsley, A. F., Vanden Bergh, R. G., \& Bonardi, J. P. 2012. Political markets and regulatory uncertainty: Insights and implications for integrated strategy. Academy of Management Perspectives, 26: 52-67.

Kogut, B. 1985. Designing global strategies: Comparative and competitive value-added chains. Sloan Management Review, 26: 27-38.

Kogut, B., \& Kulatilaka, N. 1994. Operating flexibility, global manufacturing, and the option value of a multinational network. Management Science, 40: 1-168.

Kogut, B., \& Singh, H. 1988. The effect of national culture on the choice of entry mode. Journal of International Business Studies, 19: 411-432.

Krishnan, R., Geyskens, I., \& Steenkamp, J. B. 2016. The effectiveness of contractual and trust-based governance in strategic alliances under behavioral and environmental uncertainty. Strategic Management Journal, 37: 2521-2542.

Laeven, L., \& Valencia, F. 2018. Systemic banking crises revisited. IMF Working Paper 18/206.

Lee, K. H. 2018. Cross-border mergers and acquisitions amid political uncertainty: A bargaining perspective. Strategic Management Journal, 39: 2992-3005.

Lijphart, A. 1994. Democracies: Forms, performance, and constitutional engineering. European Journal of Political Research, 25: 1-17.

Liu, C., \& Li, D. 2020. Divestment response to host-country terrorist attacks: Inter-firm influence and the role of temporal consistency. Journal of International Business Studies, 51: 1331-1346.

Liu, W., \& Ngo, P. 2014. Elections, political competition and bank failure. Journal of Financial Economics, 112: 251-268.

Lizzeri, A., \& Persico, N. 2001. The provision of public goods under alternative electoral incentives. American Economic Review, 91: 225-239.

Meyer, K., van Witteloostuijn, A., \& Beugelsdijk, S. 2017. What's in a $p$ ? Reassessing best practices for conducting and reporting hypothesis-testing research. Journal of International Business Studies, 48: 535-551.

Milesi-Ferretti, G. M., Perotti, R., \& Rostagno, M. 2002. Electoral systems and public spending. Quarterly Journal of Economics, 117: 609-657.

Moschieri, C., \& Blake, D. 2019. The organizational implications of Brexit. Journal of Organizational Design, 1: 6. 
Mudambi, R., \& Navarra, P. 2003. Political culture and foreign direct investment: The case of Italy. Economics of Governance, 4: 37-56.

Mudambi, R., \& Navarra, P. 2004. Electoral strategies in mixed systems of representation. European Journal of Political Economy, 20: 227-253.

Murtha, T., \& Lenway, S. 1994. Country capabilities and the strategic state: How national political institutions affect multinational corporations' strategies. Strategic Management Journal, 15: 113-129.

Nannicini, T., Stella, A., Tabellini, G., \& Troiano, U. 2013. Social capital and political accountability. American Economic Journal: Economic Policy, 5: 222-250.

Nguyen, Q., Kim, T., \& Papanastassiou, M. 2018. Policy uncertainty, derivatives use, and firm-level FDI. Journal of International Business Studies, 49: 96-126.

Norris, P. 1997. Choosing electoral systems: Proportional, majoritarian and mixed systems. International Political Science Review, 18: 297-312.

North, D. 1990. Institutional change and economic performance. Cambridge University Press.

Oh, C. H., \& Oetzel, J. 2011. Multinationals' response to major disasters: How does subsidiary investment vary in response to the type of disaster and the quality of country governance. Strategic Management Journal, 32: 658-681.

Pagano, M., \& Volpin, P. F. 2005. The political economy of corporate governance. American Economic Review, 95: 1005-1030.

Pastor, L., \& Veronesi, P. 2012. Uncertainty about government policy and stock prices. Journal of Finance, 67: 1219-1264.

Pastor, L., \& Veronesi, P. 2013. Political uncertainty and risk premia. Journal of Financial Economics, 110: 520-545.

Pennisi, A. 1998. Disproportionality indexes and robustness of proportional allocation methods. Electoral Studies, 17(1): 3-19.

Persson, T., \& Tabellini, G. 2004. Constitutions and economic policies. Journal of Economic Perspectives, 18: 75-98.

Persson, T., Roland, G., \& Tabellini, G. (2007). Electoral rules and government spending in parliamentary democracies. Quarterly Journal of Political Science, 2(2): 155-188.

Persson, T., Tabellini, G., \& Trebbi, F. (2003). Electoral rules and corruption. Journal of the European Economic Association, 1(4): 958-989.

Podolny, J. 1994. Market uncertainty and the social character of economic exchange. Administrative Science Quarterly, 39: 458-483.

Powell, G. B., \& Powell, G. B, Jr. (2000). Elections as instruments of democracy: Majoritarian and proportional visions. Yale University Press.

Przeworski, A., \& Limongi, F. 1993. Political regimes and economic growth. Journal of Economic Perspectives, 3(3): $51-69$.

Rae, D. W. 1967. The political consequences of electoral laws. Yale University Press.

Reeb, D., Kwok, C., \& Baek, H. 1998. Systematic risk of the multinational corporation. Journal of International Business Studies, 29: 263-279.

Reuer, J., \& Leiblein, M. 2000. Downside risk implications of multinationality and international joint ventures. Academy of Management Journal, 43: 203-214.

Rugman, A. 1976. Risk reduction by international diversification. Journal of International Business Studies, 7: 75-80.

Sarkar, A. 2020. Policy uncertainty, multinational firms, and reallocation. Working Paper.
Soule, S., Swaminathan, A., \& Tihanyi, L. 2014. The diffusion of foreign divestment from Burma. Strategic Management Journal, 35: 1032-1052.

Taagepera, R. 2002. Nationwide threshold of representation. Electoral Studies, 21: 383-401.

Thompson, J. D. 1967. Organizations in action: Social science bases of administrative theory. McGraw-Hill.

Tong, W., \& Reuer, J. 2007. Real options in multinational corporations: Organizational challenges and risk implications. Journal of International Business Studies, 38: 215-230.

Van de Ven, A. H. 1979. Review of Aldrich's (1979) book organization and environments. Administrative Science Quarterly, 24: 320-326.

Van de Ven, A. H., \& Drazin, R. 1985. The concept of fit in contingency theory. In L. L. Cummings, \& B. M. Staw (Eds.), Research in organizational behavior: 333-365, vol. 7. JAl.

Vuchelen, J. 2003. Electoral systems and the effects of political events on the stock market: The Belgian case. Economics and Politics, 15: 85-102.

Wernerfelt, B., \& Karnani, A. 1987. Competitive strategy under uncertainty. Strategic Management Journal, 8: 187-194.

Yan, J. Z., \& Chang, S. J. 2018. The contingent effects of political strategies on firm performance: A political network perspective. Strategic Management Journal, 39: 2152-2177.

Zhong, W., Lin, Y., Gao, D., \& Yang, H. 2019. Does politician turnover affect foreign subsidiary performance: Evidence from China. Journal of International Business Studies, 50: 1184-1212.

Zingales, L. 2017. Towards a political theory of the firm. Journal of Economic Perspectives, 31: 113-130.

\section{APPENDIX 1: INVESTMENT AND TIME TO FORM A GOVERNMENT}

Dependent variable: Investment

(1)

Time to form a government

$-0.0008$

GDP growth

$(0.003)$

size

(0.000)

Firm size

0.0053

M1

EPU

$(0.000)$

EPU

Interest rate

$-0.0198$

Industry $\times$ Year effects

Firm fixed effects

Yes

Observations

344,365

$p$ values are reported in parentheses. Standard errors are clustered by firm. 


\section{APPENDIX 2: INVESTMENT AND POST- ELECTION PERIODS}

\begin{tabular}{lll}
\hline & $\begin{array}{l}\text { Subsample } \\
\text { Plurality }=1 \\
(1)\end{array}$ & $\begin{array}{l}\text { Subsample } \\
\text { Plurality }=0 \\
(2)\end{array}$ \\
\hline Dependent variable: & Investment & \\
Post-election & 0.0005 & -0.0024 \\
& $(0.329)$ & $(0.000)$ \\
GDP growth & 0.0005 & 0.0011 \\
& $(0.000)$ & $(0.000)$ \\
Firm size & 0.0071 & 0.0051 \\
& $(0.000)$ & $(0.000)$ \\
ROA & -0.0253 & 0.0028 \\
& $(0.000)$ & $(0.422)$ \\
M1 & 0.0001 & -0.0003 \\
& $(0.011)$ & $(0.000)$ \\
EPU & -0.0122 & -0.0242 \\
& $(0.000)$ & $(0.000)$ \\
Interest rate & -0.0003 & -0.0008 \\
Industry $\times$ Year & $(0.029)$ & $(0.000)$ \\
effects & Yes & Yes \\
Firm fixed effects & Yes & \\
Observations & 217,152 & Yes \\
\hline P & & 178,995 \\
\hline
\end{tabular}

$p$ values are reported in parentheses. Standard errors are clustered by firm.

\section{ABOUT THE AUTHORS}

Mario Daniele Amore is Associate Professor at Bocconi University, and Research Affiliate at the Centre for Economic Policy Research (CEPR). He received a PhD in Economics and Management from Copenhagen Business School. Mario's research lies at the intersection of strategy, corporate governance and corporate finance. His works have appeared in leading journals including Management Science, Journal of Financial Economics, Strategic Management Journal, and Organization Science.

Margherita Corina is currently a $\mathrm{PhD}$ student in Business Administration \& Management at Bocconi University. She earned a Master and Bachelor in Economics and Social Sciences from Bocconi University, as well as a Master in Economic Policy Management from Columbia University and in Public Policy from ITAM. Her research examines the relationships between firms' strategies and environmental uncertainty.

Open Access This article is licensed under a Creative Commons Attribution 4.0 International License, which permits use, sharing, adaptation, distribution and reproduction in any medium or format, as long as you give appropriate credit to the original author(s) and the source, provide a link to the Creative Commons licence, and indicate if changes were made. The images or other third party material in this article are included in the article's Creative Commons licence, unless indicated otherwise in a credit line to the material. If material is not included in the article's Creative Commons licence and your intended use is not permitted by statutory regulation or exceeds the permitted use, you will need to obtain permission directly from the copyright holder. To view a copy of this licence, visit http://creativecommons.org/licenses/by/4.0/.

Publisher's Note Springer Nature remains neutral with regard to jurisdictional claims in published maps and institutional affiliations.

Accepted by Arjen vanWitteloostuijn, Area Editor, 21February 2021. This article hasbeen with the authors for threerevisions. 